\title{
Abstracts/Résumés
}

\section{The Subclassification of Southern Wakashan}

\author{
William H. Jacobsen, Jr., University of Nevada
}

\begin{abstract}
The Southern Wakashan (or Nootkan) languages exhibit a sort of chain relationship, from south to north: Makah, Nitinat, and Nootka. Given the intermediate geographic position of Nitinat with respect to Makah (situated more to the south) and Nootka (situated more to the north), one can ask which of these languages is most closely related to Nitinat. At present, this question remains unresolved, as reflected by the disagreement in the literature. Relying primarily on lexical data, but also considering aspects of sound changes and grammatical criteria, it is proposed that the closer grouping of Nitinat is with Makah.
\end{abstract}

\section{Résumé}

Les langues wakashannes (ou nootkannes) du sud entretiennent des rapports géographiques en chaîne, s'étalant du sud jusqu'au nord : le makah, le nitinat et le nootka. Étant donné la position géographiquement intermédiaire du nitinat par rapport au makah (situé plus au sud) et au nootka (situé plus au nord), on peut se demander laquelle de ces deux langues est la plus rapprochée du nitinat. À présent, cette question demeure non résolue, si on se fie au désaccord dans la littérature sur le sujet. En se basant essentiellement sur des données lexicales, et aussi sur certains aspects de changements phonologiques et de critères grammaticaux, il est ici proposé que le nitinat et le makah constituent le regroupement le plus rapproché. 


\title{
The Effects of Post-Velar Consonants on Vowels in Nuu-chah-nulth: Auditory, Acoustic, and Articulatory Evidence
}

Ian Wilson, University of British Columbia/University of Aizu

\begin{abstract}
Previous phonetic documentation of Nuu-chah-nulth consonant-vowel interactions has either solely relied on transcriptions or has been incomplete in some other respect. Using auditory, acoustic, and articulatory evidence, this article documents the effects of all post-velar consonants on all vowels. Results show that /i/ and /i:/ almost always have a schwa offglide before the uvular and pharyngeal stops, but not always before the fricatives. When these vowels follow uvulars and pharyngeals (with the exception of the labialized uvular), they are usually lowered and do not have a schwa offglide. Ultrasound data confirm that the tongue root is active in articulating uvular and pharyngeal consonants and that the schwa offglide occurs because the tongue is moving through a schwa-like configuration on its way from the high front vowel to the retracted consonant. The vowels $/ \mathrm{u} /$ and /u:/ are lowered and/or diphthongized following (but not preceding) pharyngeals, and they are unaffected by uvulars.
\end{abstract}

\section{Résumé}

Les études phonétiques antérieures sur l'interaction des consonnes et des voyelles en nuu-chah-nulth se sont basées exclusivement sur des transcriptions ou ont été incomplètes à d'autres égards. En utilisant des données auditives, acoustiques et articulatoires, cet article documente les effets de toutes les consonnes postvélaires sur toutes les voyelles. Les données démontrent que /i/ et /i:/ sont presque toujours relâchés vers un schwa devant les occlusives uvulaires et pharyngiennes, mais que ce relâchement n'est pas toujours présent devant les fricatives. Lorsque ces voyelles apparaissent après les uvulaires et les pharyngiennes (exception étant faite de l'uvulaire labialisée), elles sont généralement abaissées et non pas relâchées vers un schwa. Les données ultrasonores confirment que la racine de la langue est active dans l'articulation des consonnes uvulaires et pharyngiennes et que le relâchement vers le schwa est dû au déplacement de la voyelle haute avancée vers la consonne rétractée, occupant au passage une configuration qui ressemble à celle du schwa. Les voyelles /u/ et /u:/ sont abaissées et/ou diphtonguées suivant (mais non pas précédant) les pharyngiennes et elles ne sont pas altérées par les uvulaires. 


\title{
Ditidaht Vowel Alternations and Prosody
}

\author{
Adam Werle, University of Massachusetts, Amherst
}

\begin{abstract}
Among the Southern Wakashan languages, Ditidaht has patterns of short vowel epenthesis and deletion that are unusually complex. It is shown that the surface presence or absence of short vowels is determined not by their underlying presence or absence, but by how segments are parsed by prosodic constituents. An optimality theoretic analysis is developed, according to which vowel alternations result from the low ranking of faithfulness constraints (MAX/V and DEP/V) relative to constraints on the forms of syllables, feet, and prosodic words. Vowel presence creates ideal iambic feet, makes prosodic words minimally disyllabic, and ensures that adducted consonants (those that involve adducting the vocal folds for glottalization or voicing) are vowel-adjacent. Vowel absence ensures that prosodic words end in consonants, and eliminates unfooted syllables. An additional finding is that all adducted consonants must be postvocalic.
\end{abstract}

\section{Résumé}

Parmi les langues wakashannes du sud, le ditidaht présente des processus d'épenthèse et d'effacement de voyelles courtes qui sont particulièrement complexes. Il est ici démontré que la présence ou l'absence en surface de voyelles courtes est régie non pas par leur présence ou absence sous-jacente, mais par les computations prosodiques des segments de mots. Une analyse formulée dans la théorie de l'optimalité est développée, selon laquelle les alternances vocaliques résultent du rangement bas des contraintes de préservation ( $\mathrm{MAX} / \mathrm{V}$ et $\mathrm{DEP} / \mathrm{V})$ relativement aux contraintes sur la forme des syllabes, des pieds et des mots prosodiques. La présence d'une voyelle crée un pied iambique idéal, rendant les mots prosodiques minimalement dissyllabiques et assurant que les consonnes adductives (celles qui impliquent l'adduction des cordes vocales pour la glottalisation ou le voisement) soient adjacentes à une voyelle. L'absence d'une voyelle permet qu'un mot prosodique se termine avec une consonne et qu'ainsi, chaque syllabe appartienne à un pied. Une constatation additionnelle est que les consonnes adductives doivent être postvocaliques. 


\title{
Nuuchahnulth Double Reduplication and Stratal Optimality Theory
}

\author{
John Stonham, Pukyong National University, South Korea
}

\begin{abstract}
Multiple reduplication is rare: the most often cited case is that of Salish double reduplication, which has been analyzed within the framework of Optimality Theory. For this reason, the simple and double reduplication processes found in Nuuchahnulth (Nootka) have theoretically interesting consequences for current models of morphology. This article demonstrates that Nuuchahnulth double reduplication challenges the standard, parallelist optimality theoretic account. An alternative analysis in terms of Stratal Optimality Theory is presented: the multistratal model is argued to be superior to the mono-stratal one, as the latter misses generalizations and fails to make correct predictions.
\end{abstract}

\section{Résumé}

Le redoublement multiple est rare : le cas le plus souvent cité est celui du double redoublement dans les langues salishennes, qui a été analysé dans le cadre de la théorie de l'optimalité. Ainsi, les processus de redoublement simple et double que l'on retrouve en nuuchahnulth (nootka) ont des enjeux théoriques intéressants pour les modèles de morphologie contemporains. Cet article démontre que le double redoublement en nuuchahnulth est problématique pour l'analyse standard paralléliste de la théorie de l'optimalité. Une analyse alternative est présentée dans le cadre de la théorie de l'optimalité stratifiée : le modèle multi-stratifié est supérieur au modèle mono-stratifié en ce que ce dernier ne rend pas compte de certaines généralisations et ne produit pas de bonnes prédictions. 


\title{
What to do to 'do-to... '? Notes on an Object Marker in Nuu-chah-nulth
}

\author{
Florence Woo, University of California, Santa Cruz
}

\begin{abstract}
The syntactic behaviour of the object marker ?uuk ${ }^{W_{i}}$ in Nuu-chah-nulth is documented based on fieldwork data that illustrate patterns not previously discussed in the literature. A Minimalist-type analysis is presented, in which ?uuk ${ }^{w} i 1$ is a light verb of the category $v$ and is generated in the complement position of the main verb. This captures certain traits of ?uuk $k^{w i f}$ that have hitherto not been unified under a single analysis: its morphological and syntactic autonomy, its semantic dependence on another predicate for argument structure, its link to discourse saliency, and its use as an auxiliary item in $\mathrm{A}^{\prime}$-raising constructions.
\end{abstract}

\section{Résumé}

Le comportement syntaxique du marqueur d'objet ?uuk $k^{W_{i}}$ en nuu-chah-nulth est ici documenté sur la base de données de terrain illustrant des propriétés qui n'ont pas été traités antérieurement dans la littérature. Une analyse de type minimaliste est présentée, dans laquelle ?uuk ${ }^{w i ł ~ e s t ~ u n ~ v e r b e ~ l e ́ g e r ~ d e ~ c a t e ́ g o r i e ~} v$ généré dans la position de complément du verbe principal. Ceci rends compte de certains traits de $? u k^{w_{i}}$ ił qui demeurent sans analyse unifiée, soit : son autonomie morphologique et syntaxique, sa dépendance sémantique à autre prédicat pour sa structure d'argument, son rapport à la mise-en-relief discursive et son emploi comme auxiliaire dans les constructions impliquant le déplacement $\mathrm{A}^{\prime}$. 


\title{
Possessor Raising in Nuu-chah-nulth
}

\author{
Christine Ravinski, University of British Columbia
}

\begin{abstract}
Nuu-chah-nulth possessor raising is semantically unrestricted and affects only subjects: subject agreement matches the person and number of the possessor (rather than the possessed subject), and the possessive-marking clitic attaches to the head of the clause (rather than to the possessum). Nuu-chah-nulth possessor raising is analyzed as a syntactic dependency between the possessive clitic in the main clause and the base-generated possessor position within DP. A Possessive Phrase can appear in either the DP or the clausal domain, and the possessive clitic may be generated in either position. When the possessive clitic is generated in the main clause, a possessor may raise out of subject position via feature-driven movement; the Minimal Link Condition prevents such movement from occurring out of object position.
\end{abstract}

\section{Résumé}

En nuu-chah-nulth, le déplacement du possesseur n'est pas sujet à des contraintes sémantiques et peut seulement cibler la position de sujet. L'accord sujet (en personne et en nombre) s'effectue avec le possesseur (plutôt que le sujet possédé) et le clitique possessif s'attache à la tête de la phrase (plutôt que sur le possessum). Le déplacement du possesseur en nuu-chah-nulth est ici analysé comme une dépendance syntaxique entre le clitique possessif dans la phrase matrice et la position de possesseur à l'intérieur du syntagme déterminant (SD). Un Syntagme Possessif peut apparaître soit dans le SD ou dans le domaine de la phrase matrice et le clitique possessif peut être généré dans l'une ou l'autre de ces deux positions. Lorsque le clitique possessif est engendré dans la phrase matrice, un possesseur peut se déplacer depuis la position sujet via le mouvement légitimé par la vérification de traits; la condition sur le lien minimal empêche par ailleurs que l'origine de ce mouvement soit la position d'objet. 


\title{
Condition C Effects in Nuu-chah-nulth
}

\author{
Henry Davis, University of British Columbia \\ Ryan Waldie, University of British Columbia \\ Rachel Wojdak, University of British Columbia/University of Ottawa
}

\begin{abstract}
Nuu-chah-nulth presents a set of exceptions to Condition C of the Binding Theory that involves co-construal between certain $\mathrm{R}$-expressions and a c-commanding pronoun. These exceptions to Condition $\mathrm{C}$ are not reducible to structural properties of the language, and are not confined to coreference anaphora, as they extend to bound variables without quantificational antecedents. Nuu-chah-nulth also shows strong crossover effects, and more generally obeys a strict c-command condition on variables bound by quantifiers. We account for these facts by distinguishing quantifier binding from other types of dependent reference, and parameterize the latter based on reverse dependency, where a pronoun may precede and/or c-command its antecedent. Reverse dependency reflects the nonpresuppositional nature of Nuu-chah-nulth pronouns, which allows them to be introduced ahead of their descriptive content.
\end{abstract}

\section{Résumé}

Le nuu-chah-nulth présente une série d'exceptions à la condition $\mathrm{C}$ de la théorie du liage qui implique une dépendance entre certaines expressions- $\mathrm{R}$ et le pronom qui les $\mathrm{c}$-commande. Ces exceptions à la condition $\mathrm{C}$ ne sont pas réductibles aux propriétés structurales de la langue et ne sont pas restreintes à des contextes de coréférence anaphorique, puisqu'elles sont attestées avec des variables liées sans antécédents quantificationnels. Le nuu-chah-nulth présente aussi des effets de strong crossover et plus généralement il obéit à une condition stricte de ccommande sur les variables liées par quantifieur. Nous rendons compte de ces faits en distinguant le liage quantificationnel des autres types de référence dépendante et nous paramétrons cette dernière en termes de dépendance inverse, par laquelle un pronom peut précéder et/ou c-commander son antécédent. La dépendance inverse découle de la nature non-présuppositionnelle des pronoms en nuu-chah-nulth, ce qui leur permet d'être introduits avant leur contenu descriptif. 